\title{
Carboxytherapy in the light of the latest reports. Erythema multiforme-like eruption as a side effect of carboxytherapy
}

\author{
Karboksyterapia w świetle najnowszych doniesień. Zmiany skórne typu rumienia \\ wielopostaciowego indukowane wirusem opryszczki jako powikłanie zabiegu \\ karboksyterapii
}

Wioletta Barańska-Rybak, Dorota M. Mehrholz

Department of Dermatology, Venereology and Allergology, Medical University of Gdansk, Poland

Klinika Dermatologii, Wenerologii i Alergologii Gdańskiego Uniwersytetu Medycznego, Polska

Dermatol Rev/Przegl Dermatol 2019, 106, 46-51

DOI: https://doi.org/I0.5। |4/dr.2019.83443

\author{
CORRESPONDING AUTHOR/ \\ ADRES DO KORESPONDENCJI: \\ lek. Dorota M. Mehrholz \\ Klinika Dermatologii, \\ Wenerologii i Alergologii \\ Gdański Uniwersytet Medyczny \\ ul. Dębinki 7 \\ 80-211 Gdańsk, Poland \\ tel.: +48515157137 \\ e-mail: mehrholz@gumed.edu.pl
}

\begin{abstract}
Carboxytherapy is a very popular method applied in aesthetic medicine. The procedure is used for the reduction of cellulite, atrophic scarring and stretch marks, treatment of localized adiposities, wrinkle correction and rejuvenation of the skin. It is claimed that carbon dioxide therapy is a very safe procedure with only a small number of complications. Pain, oedema and bruising of the injection area are often side effects of carboxytherapy. There are only a few reports of more serious complications such as subcutaneous emphysema or Mycobacterium infection. The following is the first case report of herpes-associated erythema multiforme caused by carboxytherapy. A 41-year-old woman consulted a dermatologist because of erythematous skin lesions with brightening in the central part of the macules which appeared three days after the carboxytherapy. In the anamnesis recurrent herpes labialis was noted.
\end{abstract}

\section{STRESZCZENIE}

Karboksyterapia jest bardzo popularnym zabiegiem wykorzystywanym w medycynie estetycznej: w redukcji cellulitu, blizn zanikowych i rozstępów, a także w leczeniu miejscowych otłuszczeń, korekcji zmarszczek i odnowie skóry. Uważa się, że jest to bardzo bezpieczny zabieg obarczony małą liczbą powikłań. Do częstych działań ubocznych karboksyterapii należą: ból, obrzęk i zasinienia w miejscu iniekcji. Znane są tylko pojedyncze doniesienia dotyczące bardziej poważnych powikłań, takich jak odma podskórna lub zakażenie prątkami niegruźliczymi. Przedstawiamy pierwszy przypadek rumienia wielopostaciowego wywołanego infekcją wirusem opryszczki będącą powikłaniem karboksyterapii. Pacjentka w wieku 41 lat zgłosiła się do gabinetu dermatologicznego $\mathrm{z}$ powodu zmian rumieniowych $\mathrm{z}$ przejaśnieniem w centralnej części wykwitów, które pojawiły się 3 dni po karboksyterapii. W wywiadzie odnotowano nawracającą opryszczkę wargową.

Key words: complications, erythema multiforme, carboxytherapy.

Słowa kluczowe: powikłania, rumień wielopostaciowy, karboksyterapia. 
Carboxytherapy is a relatively new but increasingly popular and versatile method applied in aesthetic medicine. The origins of clinical applications of carbon dioxide $\left(\mathrm{CO}_{2}\right)$ date back to the 1930 s when it was used in baths for treatment of chronic venous insufficiency [1]. Subcutaneous application of $\mathrm{CO}_{2}$ has been performed since the 1990s to treat trophic skin lesions caused by diabetes and arteriosclerosis. Currently carboxytherapy is used for the reduction of cellulite, atrophic scarring and stretch marks, treatment of localized adiposities, wrinkle correction and skin rejuvenation.

\section{Carboxytherapy - the essentials}

Mechanism of action

Carboxytherapy is based on the Bohr effect. Insufflation of $\mathrm{CO}_{2}$ leads to a local decrease in $\mathrm{pH}$. As a result, the affinity of haemoglobin to oxygen decreases, thus allowing more oxygen to reach the treated tissue. Carbon dioxide has vasodilatory properties [2]. It is well known that in all tissues hypoxia-inducible factor 1 (HIF-1) is present. This protein is sensitive to oxygen level fluctuation. In physiological $\mathrm{pH}$ conditions it is quickly inactivated by von Hippel-Lindau protein. However, in a hypoxemic state HIF-1 degradation is inhibited, which leads to stimulation of vascular endothelial growth factor (VEGF) [3]. Thanks to this mechanism there is more angiogenesis and an overall increase in the perfusion of tissues, which are long-term benefits of carboxytherapy.

The second main effect of the procedure is stimulation of collagen synthesis. The response to hypoxia is cell necrosis, which is a triggering factor of local inflammation and fibroblast activation. Active fibroblasts can synthesize collagen and elastin $[4,5]$.

Indications for the procedure and results of clinical trials

Rejuvenating properties, improvement of tissue oxygenation and increase in venous and lymphatic circulation justify wide usage of carboxytherapy in medicine [6, 7]. Various indications for carboxytherapy also make it is an increasingly popular method in aesthetic medicine [8]. It can be an effective method of the following procedures: cellulite treatment [9], reduction of local adipose tissue $[10,11]$, treatment of atrophic scars [2, 12], wrinkle correction [13] and periorbital region rejuvenation [14].

\section{Contraindications and complications}

Carboxytherapy belongs to the group of minimally invasive procedures. However, there are two main contraindications to carboxytherapy: kidney insufficiency and lung diseases associated with hypercapnia [15].

\section{WPROWADZENIE}

Karboksyterapia jest stosunkowo nową, ale coraz bardziej popularną metodą wykorzystywaną w medycynie estetycznej. Początki zastosowania klinicznego dwutlenku węgla $\left(\mathrm{CO}_{2}\right)$ sięgają lat 30 . XX wieku, kiedy używano go do kąpieli w leczeniu przewlekłej niewydolności żylnej [1]. Podskórne podawanie $\mathrm{CO}_{2}$ jest metodą stosowaną od lat 90. ubiegłego wieku w leczeniu troficznych zmian skórnych w przebiegu cukrzycy i miażdżycy. Obecnie karboksyterapia jest wykorzystywana w redukcji cellulitu, blizn zanikowych i rozstępów, a także w leczeniu miejscowych otłuszczeń, korekcji zmarszczek i odnowie skóry.

\section{Karboksyterapia - o czym warto pamiętać \\ Mechanizm działania}

W karboksyterapii wykorzystuje się efekt Bohra. Insuflacja $\mathrm{CO}_{2}$ powoduje miejscowe obniżenie $\mathrm{pH}$. $\mathrm{W}$ rezultacie zmniejsza się powinowactwo hemoglobiny do tlenu, co umożliwia zwiększenie utlenowania tkanki docelowej. Dwutlenek węgla ma także właściwości wazodylatacyjne [2]. Jak wiadomo, we wszystkich tkankach ludzkiego organizmu występuje czynnik indukowany hipoksją 1 (HIF-1). Białko to jest wrażliwe na zmiany stężenia tlenu. Przy fizjologicznym pH szybko ulega inaktywacji przez białko von Hippla-Lindaua, jednak w warunkach niedotlenienia degradacja HIF-1 jest zahamowana, co prowadzi do stymulacji czynnika wzrostu śródbłonka naczyniowego (vascular endothelial growth factor - VEGF) [3]. Dzięki temu mechanizmowi następuje nasilenie procesu angiogenezy i ogólny wzrost perfuzji tkanek, które stanowią długofalowe korzyści z karboksyterapii.

Drugą zasadniczą korzyścią z zabiegu jest pobudzenie syntezy kolagenu. W reakcji na niedotlenienie następuje nekroza komórek, która wywołuje miejscowy stan zapalny i aktywację fibroblastów. Aktywne fibroblasty mają zdolność syntezy kolagenu i elastyny $[4,5]$.

\section{Wskazania do zabiegu i wyniki badań klinicznych}

Właściwości odmładzające, poprawa utlenowania tkanek oraz nasilenie krążenia żylnego i limfatycznego uzasadniają szerokie zastosowanie karboksyterapii w medycynie [6, 7]. Dzięki szerokiemu zakresowi wskazań karboksyterapia zyskuje coraz większe znaczenie w medycynie estetycznej [8]. Przynosi korzystne efekty między innymi w leczeniu cellulitu [9], redukcji miejscowych otłuszczeń [10, 11], usuwaniu blizn zanikowych [2, 12], korekcji zmarszczek [13] oraz w zabiegach odmładzających skórę wokół oczu [14].

\section{Przeciwwskazania i powikłania}

Karboksyterapia należy do zabiegów minimalnie inwazyjnych. Znane są jednak dwa zasadnicze 


\section{OBJECTIVE}

The aim of the study was to enhance physicians' awareness about side effects of carboxytherapy, because it is claimed that it is a procedure without complications.

\section{CASE REPORT}

The following is the first case report of herpes-associated erythema multiforme inflicted by carboxytherapy.

A 41-year-old female patient was consulted in a dermatology outpatient clinic with erythematous dusky centred plaques localized on the skin of the abdomen (fig. 1). The first skin lesions appeared 3 days after a carboxytherapy procedure due to the treatment of localized adiposities performed by a beautician. According to the patient, the first vesicles appeared in the umbilicus followed by erythematous plaques on the skin of the abdomen as well as vesicles on the upper lip. The patient's past medical history indicated susceptibility to herpes labialis. Small multiple vesicles were noticed on the left upper lip as well as around the umbilicus as the Koebner phenomenon within the area of the skin injury (scratches induced by a needle) during physical examination (figs. 2 and 3). Additionally, erythematous skin lesions were present on the neck and chest of the patient (fig. 4). No mucosal or systemic symptoms were reported. Based on the clinical symptoms erythema multiforme (EM) induced by herpes simplex virus (HSV) infection was diagnosed. The patient was treated with acyclovir $800 \mathrm{mg} 6$ times daily p.o. for 6 days due to a large area of herpes infection. Levocetirizine dihydrochloride $5 \mathrm{mg}$ once daily p.o. and topically with 3\% denotivir cream were applied every 4 hours for 6 days with a good clinical outcome (figs. 5, 6).

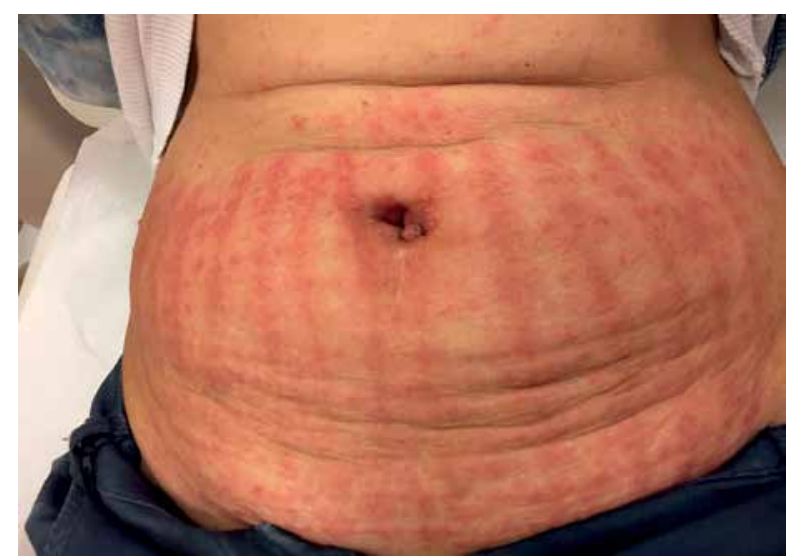

Figure I. Erythematous target-like lesions localized in the procedure area

Rycina I. Zmiany rumieniowe o koncentrycznym układzie w miejscu zabiegu przeciwwskazania do jej wykonywania: niewydolność nerek i choroby płuc przebiegające $\mathrm{z}$ hiperkapnią [15].

\section{CEL PRACY}

Celem pracy jest zwiększenie wiedzy lekarzy o potencjalnych skutkach ubocznych karboksyterapii, ponieważ panuje przekonanie, że jest to zabieg pozbawiony powikłań.

\section{OPIS PRZYPADKU}

Przedstawiamy pierwszy przypadek rumienia wielopostaciowego indukowanego zakażeniem wirusem opryszczki, który wystąpił jako powikłanie karboksyterapii.

Kobieta 41-letnia zgłosiła się do gabinetu dermatologicznego z powodu zmian rumieniowych z przejaśnieniem w centralnej części wykwitu, umiejscowionych na skórze brzucha (ryc. 1). Zmiany pojawiły się po 3 dniach od zabiegu karboksyterapii wykonanego w gabinecie kosmetycznym z powodu miejscowych otłuszczeń. Według pacjentki w pierwszej kolejności wystąpiły zmiany pęcherzykowe na skórze wokół pępka, a następnie wykwity rumieniowe na skórze brzucha oraz pęcherzyki w okolicy wargi górnej. W wywiadzie (dokumentacji medycznej) odnotowano opryszczkę wargową. Podczas badania przedmiotowego zaobserwowano liczne, niewielkie zmiany pecherzykowe w okolicy wargi górnej po lewej stronie oraz wokół pępka, a także objaw Köbnera w obrębie uszkodzonej skóry (zadrapań spowodowanych igłą) (ryc. 2 i 3). Obecne były również wykwity rumieniowe na szyi i klatce piersiowej (ryc. 4). Nie stwierdzono zmian w obrębie błon śluzowych ani objawów ogólnych. Na podstawie objawów klinicznych rozpoznano rumień wielopostaciowy (erythema multifor-

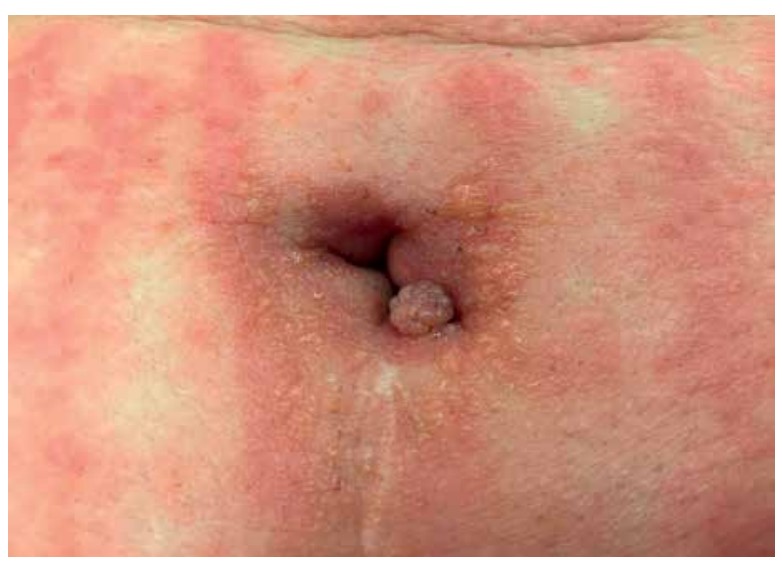

Figure 2. Vesicles in umbilical area

Rycina 2. Zmiany pęcherzykowe w okolicy pępka 


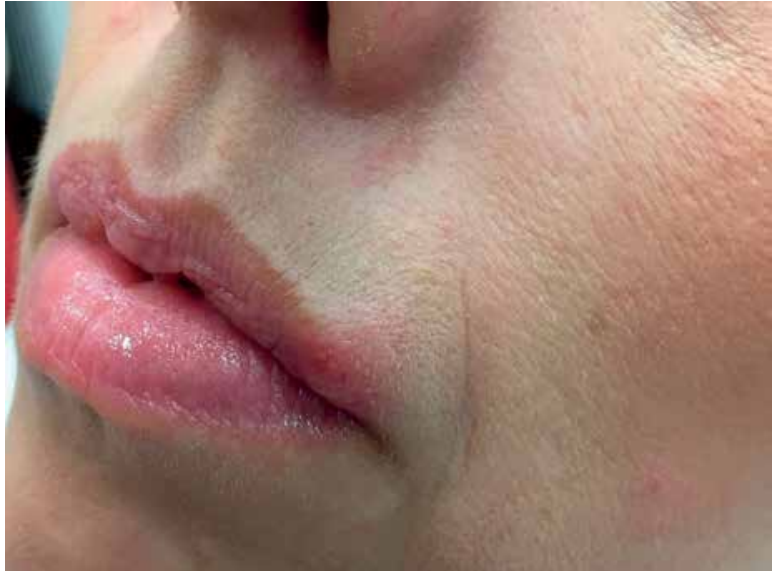

Figure 3. Skin lesions in herpes labialis course

Rycina 3. Zmiany skórne w przebiegu opryszczki wargowej

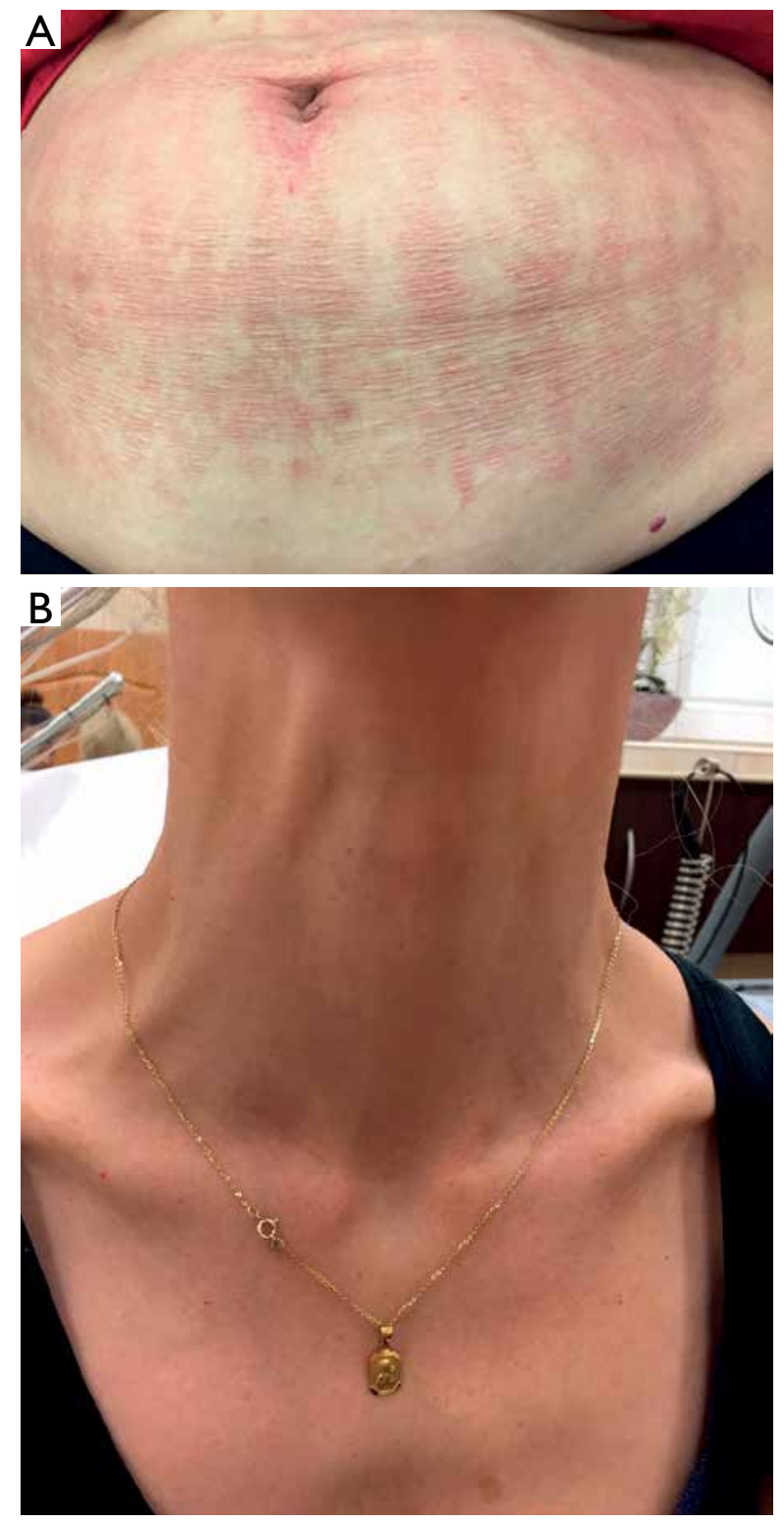

Figure 5. Skin status after treatment

Rycina 5. Stan skóry po leczeniu

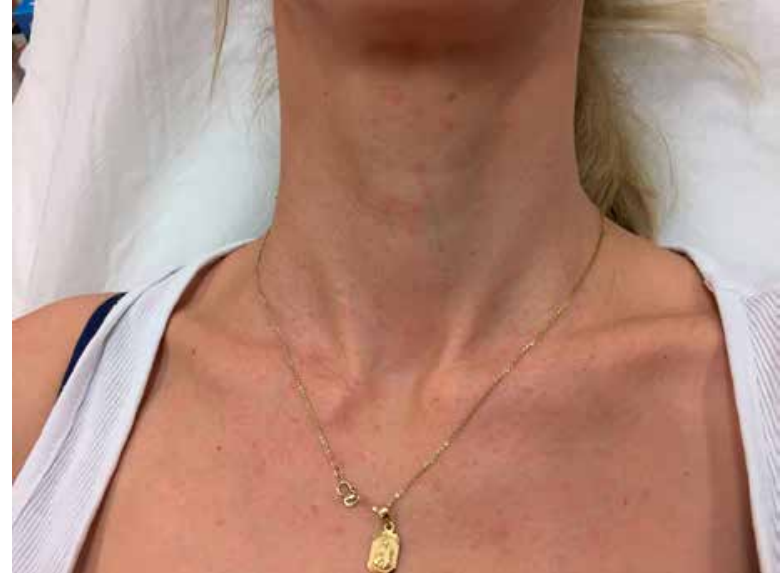

Figure 4. Erythematous skin lesions on neck Rycina 4. Zmiany rumieniowe na skórze szyi

me - EM) wywołany zakażeniem wirusem opryszczki pospolitej (HSV). U pacjentki wdrożono doustne leczenie acyklowirem w dawce $800 \mathrm{mg} 6$ razy dziennie przez 6 dni z powodu rozległej powierzchni zmian opryszczkowych. Dodatkowo pacjentka przyjmowała doustnie dichlorowodorek lewocetyryzyny w dawce $5 \mathrm{mg}$ raz na dobę oraz stosowała miejscowo krem zawierający denotywir 3\% co 4 godziny przez 6 dni, uzyskując dobry efekt kliniczny (ryc. 5, 6).

\section{OMÓWIENIE}

Przedstawiony opis przypadku wstępnie potwierdza EM jako powikłanie po karboksyterapii.

Infekcje mogą być czynnikiem etiologicznym EM. Uważa się, że EM jest najczęściej wywoływany wirusem opryszczki pospolitej (herpes simplex virus - HSV) [16]. W większości przypadków choroba jest skutkiem zakażenia wirusem HSV typu 1 i 2 . Postuluje się, że stan zapalny w obrębie zmian skórnych stanowi element swoistej dla HSV odpowiedzi immu-

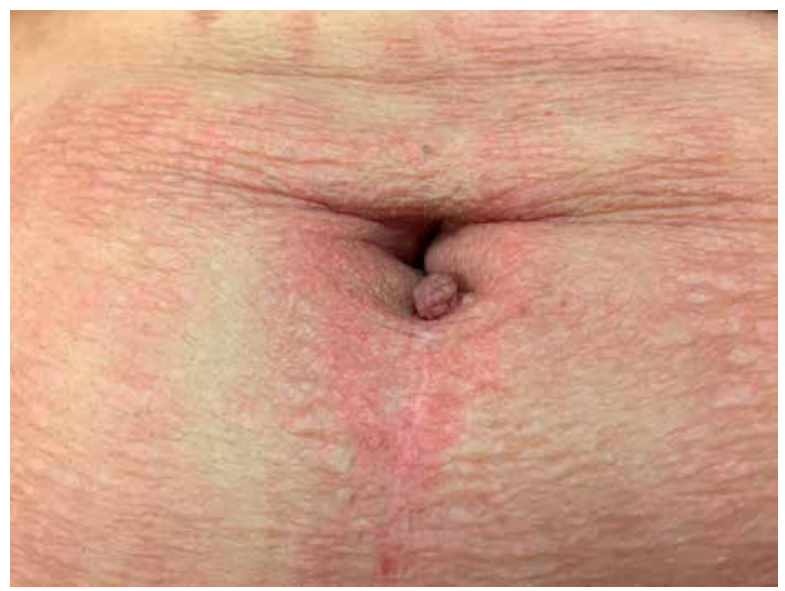

Figure 6. Umbilical area after treatment

Rycina 6. Okolica pępka po leczeniu 


\section{DISCUSSION}

This case report contains the initial documentation of EM as a complication after carboxytherapy.

Infectious diseases can be an etiologic factor of EM. It is claimed that EM most frequently is induced by the herpes simplex virus [16]. In the majority of cases the disease is precipitated by HSV types 1 and 2 . The inflammation within cutaneous lesions is believed to be a part of the HSV-specific host response [17]. Most commonly, herpes labialis proceeds target lesions of the EM by 3-14 days. Erythematous, oedematous skin lesions with typical target-like conformation are characteristic for this disease. There is a possible bullous or haemorrhagic form of EM as well. Upper and lower limbs are the most commonly affected areas, but that was not the case in the current study. Similarly, muscular and joint pain with accompanying fever can be present, but they were not observed in the present case [18].

It is claimed that carbon dioxide therapy is a very safe procedure with only a small number of complications.

Carboxytherapy treatment may cause discomfort and pain caused by the physical tissue spreading caused by the gas flow [8]. Also, some bruising from the needle can occur after the procedure. Quite often urticaria and localized swelling after $\mathrm{CO}_{2}$ can occur, which most frequently disappear after several days $[2,9]$. So far there are only a few case reports of serious complications after the procedure. In 2013 Calonge et al. described a case of subcutaneous emphysema after $\mathrm{CO}_{2}$ mesotherapy on the thighs bilaterally. The procedure resulted in gas displacement localized to the upper abdomen [19]. Moreover, there has been a report of 8 cases of Mycobacterium needle infection after $\mathrm{CO}_{2}$ injection, mainly caused by M. chelonae and M. fortuitum [20]. The risk of infection in damaged skin should always be considered when needle procedures are performed. Bacterial and viral infections are typical complications after these kinds of procedures. Staphylococcal, streptococcal and herpes simplex infections are the most frequent pathogens that affect the skin after aesthetic medicine procedures [21]. One limitation of this method is the lack of treatment parameters' standardization and small number of clinical trials confirming the efficiency of carboxytherapy. Moreover, in some beauty salons the carboxytherapy equipment exists without required certificates of quality, which can lead to an increase in the number of complications after surgery.

\section{CONCLUSIONS}

Carboxytherapy seems to be a very effective and safe procedure used in aesthetic medicine, but it carries a risk of complications. Adherence to asep- nologicznej gospodarza [17]. Opryszczka wargowa najczęściej poprzedza wystąpienie typowych dla EM koncentrycznych zmian skórnych o 3-14 dni. Charakterystyczne dla choroby są rumieniowo-obrzękowe zmiany skórne o wyglądzie tarczy strzelniczej. Rumień wielopostaciowy może również występować w postaci pęcherzowej lub krwotocznej. Najczęściej zajęta jest skóra kończyn górnych i dolnych, choć nie dotyczyło to opisanego przypadku. U pacjentów obserwuje się bóle mięśniowo-stawowe $\mathrm{z}$ towarzyszącą gorączką, ale ich również nie stwierdzono w przedstawionym przypadku [18].

Uważa się, że karboksyterapia jest stosunkowo bezpiecznym zabiegiem, obarczonym niewielką liczbą powikłań.

Metoda ta może jednak wywoływać dyskomfort i ból spowodowany fizycznym rozszerzaniem się tkanek wskutek przepływu gazu [8]. Po zabiegu może także pojawić się zasinienie w miejscu iniekcji. Dość często po podaniu $\mathrm{CO}_{2}$ występują pokrzywka i miejscowe obrzęki, które najczęściej ustępują w ciągu kilku dni [2, 9]. Dotychczas opisano zaledwie kilka przypadków ciężkich powikłań po tym zabiegu. W 2013 r. Calonge przedstawił przypadek odmy podskórnej, która pojawiła się obustronnie na udach po mezoterapii $\mathrm{CO}_{2}$. Zabieg spowodował przemieszczenie gazu zlokalizowanego w górnej części brzucha [19]. Odnotowano ponadto 8 przypadków zakażeń prątkami niegruźliczymi, głównie $M$. chelonae i $M$. fortuitum, wskutek kontaktu ze skażoną igłą podczas iniekcji $\mathrm{CO}_{2}$ [20]. Podczas zabiegów wykonywanych za pomocą igły należy zawsze uwzględniać ryzyko zakażenia uszkodzonej skóry. Typowymi powikłaniami, które towarzyszą zabiegom tego typu, są zakażenia bakteryjne i wirusowe. Po zabiegach medycyny estetycznej najczęściej obserwuje się zakażenia skóry gronkowcami i paciorkowcami oraz wirusem opryszczki zwykłej [21]. Do ograniczeń karboksyterapii należą brak standaryzacji parametrów leczenia i niewielka liczba badań klinicznych potwierdzających jego skuteczność. Ponadto urządzenia do karboksyterapii używane w niektórych gabinetach kosmetycznych nie mają wymaganych certyfikatów jakości, co może powodować wzrost liczby powikłań po zabiegu.

\section{WNIOSKI}

Wydaje się, że karboksyterapia jest bardzo skutecznym i bezpiecznym zabiegiem medycyny estetycznej, który jednak wiąże się z pewnym ryzykiem wystąpienia powikłań. Przestrzeganie zasad aseptyki i stosowanie wyłącznie certyfikowanego sprzętu wysokiej jakości zmniejsza liczbę powikłań po zabiegu. Jeśli w wywiadzie u pacjenta występuje opryszczka 
tic technique and use of only high-quality certified equipment will help reduce the number of complications after the procedure. Moreover, prophylaxis with acyclovir before the carboxytherapy procedure should be introduced when the medical history revealed previous herpes labialis incidents. wargowa, zasadna jest także profilaktyka z wykorzystaniem acyklowiru przed podjęciem karboksyterapii.

\section{KONFLIKT INTERESÓW}

Autorzy nie zgłaszają konfliktu interesów.

\section{CONFLICT OF INTEREST}

The authors declare no conflict of interest.

\section{References}

\section{Piśmiennictwo}

1. Sant'Ana E.M.C., Pianez L.R.G., Custódio F.S., Guidi R.M., de Freitas J.N.: Effectiveness of carboxytherapy in the treatment of cellulite in healthy women: a pilot study. Clin Cosmet Investig Dermatol 2016, 9, 183-190.

2. Koutná N.: Carboxytherapy in aesthetic medicine. [In:] Aesthetic Medicine. P. Prendergast, M. Shiffman (eds.), Springer, Berlin Heidelberg, 2012, 547-576.

3. Lee J.W., Bae S.H., Jeong J.W., Kim S.H., Kim K.W.: Hypoxia-inducible factor (HIF-1)alpha: its protein stability and biological functions. Exp Mol Med 2004, 36, 1-12.

4. Durães E.F.R., Durães L.C., Carneiro F.P., Lino R.S., Sousa J.B.: The effect of carbon dioxide therapy on composite graft survival. Acta Cir Bras 2013, 28, 589-593.

5. Hartmann B.R., Bassenge E., Pittler M.: Effect of carbon dioxide-enriched water and fresh water on the cutaneous microcirculation and oxygen tension in the skin of the foot. Angiology 1997, 48, 337-343.

6. Sinozić T., Kovacević J.: Carboxytherapy - supportive therapy in chronic wound treatment. Acta Med Croatica 2013, 67 Suppl 1, 137-141.

7. Kamel A.M., Abdelghani R.: Carboxytherapy for treatment of localized chronic plaque psoriasis: clinical and histopathologic evaluation. J Cosmet Dermatol 2018, 17, 527-532.

8. Pinheiro N.M., Crema V.O., Millan B.M., Carvalho F.A., Mendonça A.C.: Comparison of the effects of carboxytherapy and radiofrequency on skin rejuvenation. J Cosmet Laser Ther 2015, 17, 156-161.

9. Lee G.S.K.: Carbon dioxide therapy in the treatment of cellulite: an audit of clinical practice. Aesthetic Plast Surg 2010, 34, 239-243.

10. Lee G.S.K.: Quality survey on efficacy of carboxytherapy for localized lipolysis. J Cosmet Dermatol 2016, 19, 208-211.

11. Brandi C., D'Aniello C., Grimaldi L., Caiazzo E., Stanghellini E.: Carbon dioxide therapy: effects on skin irregularity and its use as a complement to liposuction. Aesthetic Plast Surg 2004, 28, 222-225.

12. Nach R., Zandifar H., Gupta R., Hamilton J.S.: Subcutaneous carboxytherapy injection for aesthetic improvement of scars. Ear Nose Throat J 2010, 89, 64-66.

13. Nisi G., Cuomo R., Brandi C., Grimaldi L., Sisti A., D'Aniello C.: Carbon dioxide therapy and hyaluronic acid for cosmetic correction of the nasolabial folds. J Cosmet Dermatol 2016, 15, 169-175.

14. Paolo F., Nefer F., Paola P., Nicolò S.: Periorbital area rejuvenation using carbon dioxide therapy. J Cosmet Dermatol 2012, $11,223-228$.

15. Leibaschoff G.: Carboxytherapy. [In:] Cellulite: Pathophysiology and Treatment. M. Goldman, G. Leibaschoff, D. Hexcel, P. Bacci (eds.) Taylor \& Francis, 2006, 197-210.

16. Jabłońska S., Majewski S.: Choroby skóry i choroby przenoszone drogą płciową. PZWL, Warsaw, 2005.

17. Brice S.L. Stockert S.S., Bunker J.D., Bloomfield D., Huff J.C., Norris D.A., et al.: The herpes-specific immune response of individuals with herpes-associated erythema multiforme compared with that of individuals with recurrent herpes labialis. Arch Dermatol Res 1993, 285, 193-196.

18. Crețu A., Dimitriu A., Brănişteanu D., Brinişteanu D.E.: Erythema multiforme: etiopathogenic, clinical and therapeutic aspects. Rev Med Chir Soc Med Nat Iasi 2015, 119, 55-61.

19. Calonge W.M., Lesbros-Pantoflickova D., Hodina M., Elias B.: Massive subcutaneous emphysema after carbon dioxide mesotherapy. Aesthetic Plast Surg 2013, 37, 194-197.

20. Couderc C., Carbonne A., Thiolet J.M., Brossier F., Savey A., Bernet C., et al.: Infections à mycobactéries atypiques liées à des soins esthétiques en France, 2001-2010. Médecine Mal Infec 2011, 41, 379-383.

21. Urdiales-Gálvez F., Delgado N.E., Figueiredo V., Lajo-Plaza J.V., Mira M., Moreno A., et al.: Treatment of soft tissue filler complications: expert consensus recommendations. Aesthetic Plast Surg 2018, 42, 498-510.

Received: 20.01.2018

Accepted: 15.01 .2019

Otrzymano: 20.01.2018 r.

Zaakceptowano: 15.01.2019 r.

How to cite this article

Barańska-Rybak W., Mehrholz D.M.: Carboxytherapy in the light of the latest reports. Erythema multiforme-like eruption as a side effect of carboxytherapy. Dermatol Rev/Przegl Dermatol 2019, 106, 46-51. DOI: https://doi.org/10.5114/dr.2019.83443. 